\title{
O DISCURSO DA MARCA COLCCI: UM RECORTE VISUAL SOBRE O PROCESSO DE TRANSIÇÃO DA INDÚSTRIA DE MODA CATARINENSE
}

\author{
Agda Bernardete Alano* \\ Amanda Queiroz Campos*** \\ Richard Perassi Luiz de Souza*****
}

\begin{abstract}
Resumo: Neste estudo, a moda é tratada na sua relação com um tipo de empresa que, além de dispor ao mercado peças do vestuário e outros produtos, oferece também aspectos e elementos diferenciados, tangíveis e intangíveis, que participam do portfólio de uma marca de moda. Aqui, são apresentados aspectos específicos da marca Colcci na sua relação com a indústria do vestuário, caracterizando um estudo sobre o percurso empresarial e o discurso visual de uma marca de moda reconhecida no mercado brasileiro. Tradicionalmente, a indústria catarinense de vestuário focalizou o produto. Porém, a marca em estudo é um exemplo de que, agora, essa indústria se orienta também para o mercado, investindo na construção e na gestão de suas marcas. Com relação a isso, dois aspectos devem ser considerados, o primeiro é o conteúdo estilístico e o segundo é o discurso e a comunicação da marca, consolidando suas associações positivas e valores junto ao público consumidor e ao mercado em geral.
\end{abstract}

Palavras-chave: Imagem. Moda. Vestuário. Consumo simbólico.

Abstract: In this study, fashion is considered related to a specific company. This company offers to the market clothing items and other products, besides tangible and intangible aspects and elements of differentiation. All those products

\footnotetext{
* Professora na Universidade do Extremo Sul Catarinense - UNESC.

E-mail: agda_ba@hotmail.com

*** Mestranda em Design na Universidade Federal de Santa Catarina - UFSC.

E-mail: amandaqc88@gmail.com

**** Professor na Universidade Federal de Santa Catarina - UFSC.

E-mail: richard.perassi@uol.com.br
} 
correspond to the portfolio of the fashion label Colcci. Here, we present the specific aspects of Colcci and their relations with the clothing industry. So we may categorized this paper as a study of the business' trail and the visual speech of a fashion label recognized in the Brazilian market. Traditionally, the industry of Santa Catarina has focused on the product. Although, the label studied is an example that now this industry is also oriented to the market, investing efforts in the brands' construction and management. Related to that, two aspects must be considered. The first is the stylistic content. The second, is the label's communication and discourse that aim to consolidate their values and positive associations to the consumer niche and market in general.

Keywords: Image. Fashion. Clothing. Symbolic consumption.

\section{INTRODUÇÃO}

Nas últimas décadas, a cultura da moda é abordada como objeto de estudo em diversas áreas do conhecimento, envolvendo desde estudos psicossociais até pesquisas tecnológicas sobre design emocional. Isso porque $\mathrm{o}$ sistema da moda é compreendido como campo de atribuições de valores afetivos e significativos para o consumo simbólico, além de um processo de consumo de produtos materiais. Em meio a conceitos e teorias coloquiais, que circulam fora do processo de construção científica, os conhecimentos decorrentes das áreas de Filosofia, Sociologia, Psicologia, Antropologia, Design, Engenharia, Administração e Comunicação são aplicados aos processos de gestão estratégica da comunicação da marca de moda.

Neste estudo, considera-se que o processo público de construção e gestão marca é basicamente um processo de comunicação. Pois, como elemento significante, a marca é construída e configurada na expressão e comunicação, interna e externa, de seus valores e posicionamento. No caso da marca de moda, a tarefa é um pouco mais específica e complexa, porque se busca uma evolução coerente e continuada da imagem da marca, em meio a constantes alterações decorrentes do sistema cíclico e efêmero, que caracteriza a produção industrial dos artefatos da moda.

Este estado de Santa Catarina é destacado no processo de desenvolvimento histórico-mercadológico da indústria brasileira do vestuário. Todavia, grande parte do setor estadual do vestuário foi constituída a partir de empresas familiares e de produção artesanal que, primeiramente, foi sendo industrializada e, atualmente, mostra-se em processo de transição para um modelo profissional 
de gerenciamento. Assim, indústrias estaduais do setor de vestuário disputam lugar no mercado com empresas de grande porte e atuação abrangente.

Como ocorreu em pólos produtivos de outros países, há em Santa Catarina um processo de incorporação de pequenas marcas de vestuário a grandes conglomerados industriais. Isso é devidamente exemplificado no processo de aquisição da marca Colcci pelo grupo AMC Têxtil. Todavia, para o entendimento da situação é necessário considerar que, no mercado de moda da atualidade, há grandes empresas de tipo funcional ou segmentado, que são conhecidas como holdings.

A origem do termo holding é associada ao verbo em inglês to hold, que compreende os significados de segurar, manter, controlar. Holdings são "organizações altamente, estruturadas e racionalizadas que assumem a gestão financeira marcando a delicada passagem dos proprietários fundadores aos managers do marketing estratégico."1

Holdings também podem ser compreendidas como sociedades que possuem o controle integral ou majoritário de suas empresas subsidiárias. ${ }^{2}$ Portanto, a denominação holding pode ser atribuída à empresa que é controladora de outras empresas do mesmo setor ou referentes ao mesmo público-foco.

Atualmente, a marca Colcci é reconhecida e está consolidada como sendo de grande valor no mercado nacional. Além disso, a marca pode ser indicada como referência da ampliação do foco da indústria catarinense, integrando a gestão de marca e o consumo simbólico no processo de produção e comercialização de peças do vestuário.

O interesse pela gestão da marca responde a necessidades impostas pela concorrência, sendo considerada estratégica para o desenvolvimento e ampliação do negócio. O investimento na marca pode ser expresso ou representado na comunicação visual da marca, considerando-se mais especificamente a configuração da marca gráfica, como síntese da identidade visual corporativa. ${ }^{3}$ Pois, as mudanças na identidade gráfico-visual da marca assinalam dois momentos específicos no processo de comunicação. O primeiro é o momento anterior à incorporação da marca Colcci ao grupo AMC Têxtil, enquanto o segundo é o momento posterior ao processo de incorporação. As diferenças no processo expressivo-comunicativo da marca gráfica indicam também diferentes posicionamentos da marca diante dos públicos específicos e do mercado em geral. 
O discurso da marca Colcci: um recorte visual sobre o processo de transição da

indústria de moda catarinense

\section{MARCA E MODA}

No mundo globalizado, a obtenção de informações de moda não é privilégio de poucos, pois vive-se na era da multiplicidade e do excesso de dados e informações, que são disponibilizados em diversos meios de comunicação e, de maneira ainda mais profícua, na internet. Entretanto, sabe-se que dados e informações devem ser estruturados em conhecimento, servindo como representação e instrumento de interpretação da realidade.

O conhecimento do mercado de moda indica o consumo simbólico como fonte de lucro e campo de consolidação do negócio. Todavia, algumas empresas que se dedicam a fabricar produtos de moda, como peças do vestuário, ainda insistem em focalizar o produto, "sem se dar conta das implicações negativas que essa expressão tem sobre o modo de competir". ${ }^{4}$

Na cena contemporânea, algumas empresas catarinenses ainda mantêm a tradição que focaliza a qualidade do produto, como principal aspecto competitivo, de acordo com seu valor de uso e de mercadoria. Assim, não consideram devidamente o valor simbólico agregado ao negócio em função do investimento na construção e gerenciamento de marcas.

$O$ foco na qualidade do produto é essencial para se competir em qualquer nível do mercado. Porém, exceto em situações muito específicas, essa focalização deve ser ampliada com investimento no processo de agregação de valores estético-simbólicos aos produtos e à marca que os representa. Essa é uma necessidade imposta pelo público e pela concorrência devido ao amadurecimento e à internacionalização do mercado que disponibiliza a todos que dispõe das condições necessárias, o acesso a tecnologias e a materiais de produção, colocando indústrias de mesmo porte em igualdade de condições, com relação à qualidade objetiva dos produtos.

A moda e as marcas são, portanto, os aspectos de diferenciação simbólica dos produtos, cujo design demarca um estilo próprio e, ao mesmo tempo, segue as tendências internacionais. Assim, investe-se em aspectos e elementos estético-simbólicos, sem desconsiderar a qualidade objetiva dos produtos que se disponibiliza no mercado. Além da comunicação determinada por aspectos estilísticos dos produtos, as marcas e a moda também se alimentam de toda a publicidade possível, seja por meio de propaganda, de apoio a eventos, de relações públicas em geral e dos elementos gráficos de identificação visual, que são tratados de maneira mais específica neste texto.

Em Santa Catarina, a produção de vestuário é marcada pela tradição empreendedora dos imigrantes que, nas últimas décadas, conquistaram a condição de ser o segundo maior pólo têxtil e de vestuário do Brasil, sendo que o primeiro fica no estado de São Paulo. 
A produção têxtil e de vestuário é considerada parte da indústria da moda. No Brasil, essa indústria da moda foi indicada como o segundo maior empregador na área de indústria da transformação. De acordo com a Associação Brasileira da Indústria Têxtil e de Confecção no ano de 2010, a participação da cadeia têxtil representou 5,7\% do faturamento em 2010, ocupando também $17,1 \%$ da mão de obra da indústria de transformação. Em 2008, a indústria da moda de Santa Catarina obteve a segunda colocação na participação no produto interno bruto (PIB), dentro do setor têxtil nacional. Isso representou US\$ 5, bilhões, ficando atrás de São Paulo, que obteve US\$ 10,2 bilhões.

O constante crescimento do setor catarinense de produtos têxteis e vestuários situa este estado como grande produtor da indústria da moda no Brasil. Porém, a economia e o comércio globalizados, juntamente com a política brasileira de tributação, deixam essa produção sob a ameaça dos produtos asiáticos, especialmente dos chineses. ${ }^{6}$ Isso obriga os produtores brasileiros a reduzirem os custos de produção e também suas margens de lucro, para enfrentarem a concorrência externa. Diante disso, investir na marca, agregando valor simbólico aos produtos, pode significar um reforço contra a concorrência e também a possibilidade de auferir lucros maiores.

\section{O VALOR DA MARCA}

Após ter conquistado o mercado com produtos de qualidade, parte da indústria têxtil e de vestuário de Santa Catarina investe na compra, na construção e na gestão de marcas. Essas marcas constituem um patrimônio intangível das empresas, no processo de identificação e qualificação simbólica, propiciando vantagens com relação à lembrança e à preferência do público consumidor que, ainda, aceita pagar mais por produtos de marca. Essa estratégia busca enfrentar a disputa do mercado com marcas que oferecem produtos similares e, por serem mais conhecidas, conquistaram a preferência do público consumidor.

Segundo autores das áreas de Administração e Marketing interessados em branding ou gestão da marca, como Aaker ${ }^{7}$ e Martins ${ }^{8}$ são unânimes ao assinalar que o tempo de vida e o valor da marca superam o tempo de vida e o valor dos produtos que representam.

Mattos ${ }^{9}$ informou em texto da revista eletrônica Valor, publicado em 16 de setembro de 2010, que o ranking das marcas em 2010, apresentado pela consultoria internacional Interbrand, propunha a marca Coca-Cola como a mais valiosa do mundo, com o preço de US\$ 70,4 bilhões. Porém, anteriormente, em 30 de abril de 2010, a revista eletrônica Época Negócios ${ }^{10}$ informou que consultoria inglesa Millward Brown Optimor, indicava a marca Google como a 
mais valiosa do mundo, com o preço de US\$ 114 bilhões. Mas, independente dos desencontros nas avaliações feitas por empresas especializadas, as negociações de compra e venda de empresas confirmam o valor da marca. Houve na história das transações de compra de empresas casos em que o preço pago pela marca foi muitas vezes maior que o valor estimado da empresa negociada. Por exemplo, de acordo com a empresa Global Brands, ${ }^{11}$ os ativos intangíveis da empresa Arno foram avaliados em 156,3 milhões de Euros, quando essa foi vendida para o grupo francês $S E B$, no biênio 1997/1998.

Para uma empresa, a marca constitui um acervo intangível que, às vezes, chega a alcançar preço muito superior ao patrimônio tangível da organização. Todavia, o princípio constitutivo de valor é a fixação positiva da imagem de marca na mente do público consumidor e na cultura de mercado em geral. Portanto, investir na marca significa construir e atribuir-lhe valores intangíveis, que partem da boa performance dos produtos, mas também são determinados por outros benefícios experienciais e associações simbólicas.

Para Costa, ${ }^{12}$ a imagem de marca é um sistema composto como uma imagem mental ou conjunto de atributos mentais, porque se desenvolve na mente do público. Essa imagem é visualmente e sinteticamente representada pela marca gráfica. Porém, essa imagem mental é decorrente de todo tipo de experiência que o público vivencia, diante de qualquer coisa ou situação percebida e associada à empresa ou aos produtos ou aos serviços representados pela marca.

A imagem de marca emerge e se posiciona dentro da cultura de mercado, que se caracteriza como campo de emergência das marcas em geral. Por exemplo, grande parte do conjunto de adjetivos que é atribuído a uma marca, como sendo boa ou ruim e de luxo ou funcional, já existe na cultura de mercado e, geralmente, foi anteriormente atribuída a outras marcas. Portanto, a cultura de mercado é um sistema maior (macro) de onde surge a marca como um sistema menor ou uma imagem particular, reunindo, de maneira específica, diversos atributos ou adjetivos que, pelo menos em grande parte, já eram conhecidos.

A cultura é, portanto, composta como um conjunto de ideias que habita as mentes do público consumidor e também de outros públicos envolvidos. Essas ideias são representadas por objetos e situações. Assim, um chapéu pode representar a ideia de proteção, mas em certas condições representa também a ideia de autoridade. Além disso, a autoridade representada pode ser relacionada ao poder legal ou militar ou religioso. Mas, isso depende da situação em que o chapéu é percebido, podendo ser relacionado ao juiz, ao general ou ao bispo. Do mesmo modo, as associações propostas aos produtos e a outras manifestações relacionadas à marca a posiciona dentro do contexto 
cultural vigente. $\mathrm{O}$ conjunto de associações configura a cultura da marca ou a própria marca como acervo cultural. ${ }^{13}$

Depois do grande avanço industrial que produziu novos materiais e desenvolveram tecnologias cada vez mais eficientes, os valores simbólicos ou intangíveis associados à materialidade se apresentam como produtos cada vez mais rentáveis. Para De Masi, ${ }^{14}$ "são os valores do intelecto, ou seja, é importante tudo o que fazemos com o cérebro, não mais com as mãos". Assim, países mais desenvolvidos como Estados Unidos ou Japão e parte das nações da União Européia têm se dedicado, quase que exclusivamente, a produção de idéias, informações, símbolos e valores estéticos para renovarem os produtos já existentes ou para serem atribuídos aos antigos e novos produtos.

O desafio atual para as indústrias catarinenses é a atribuição de valores estético-simbólicos aos seus produtos que já são reconhecidos por suas qualidades objetivas. Na indústria de moda, há marcas catarinenses que têm conquistado o mercado nacional e o internacional, investindo no design de seus produtos e na gestão integrada da comunicação de moda, compondo e gerenciando marcas associadas a um conteúdo estilístico-emocional especificado e reconhecido pelo público. Entre essas marcas, destaca-se aqui a marca Colcci, grife catarinense de confecção de moda.

\section{A MARCA COLCCI}

Primeiramente, Colcci é o nome de uma empresa brasileira de vestuário infanto-juvenil, que foi fundada na cidade de Brusque, SC, no ano de 1986. Desde o início, a marca destacou-se pela qualidade e pelo design dos produtos, promovendo seu rápido crescimento e consolidando-se em âmbito nacional, devido à sua rede de franquias. Junto com a ampliação da abrangência da marca, cresceu o portfólio de produtos, com roupas, acessórios e outros complementos de moda, também, para o público jovem. Esse início de sucesso foi marcado pela figura simbólica da mascote "Digby" (Fig. 1), como a representação estilizada de um cachorro nas cores azul e amarela.

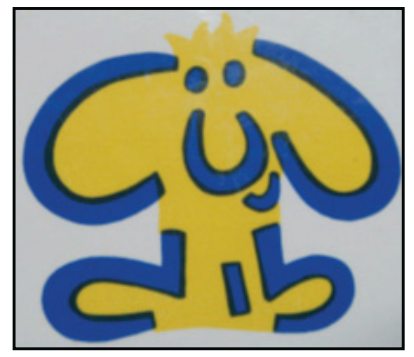

Figura 1: A mascote Digby, estilização de um cachorro nas cores azul e amarela. Fonte: Melo Filho e Merlo. ${ }^{15}$ 
A alteração do posicionamento da marca para abranger também o público jovem foi representado na transformação da marca gráfica. O logotipo da marca que, por sua composição, assumiu a aparência de figura emoldurada, com movimento que se integra ao ritmo da moldura amarela sobre o fundo azul. As composições da marca gráfica às vezes suprimiram e outras vezes integraram a figura da mascote Digby, que foi apresentada como uma figura de contornos mais definidos (Fig. 2 e 3 ).
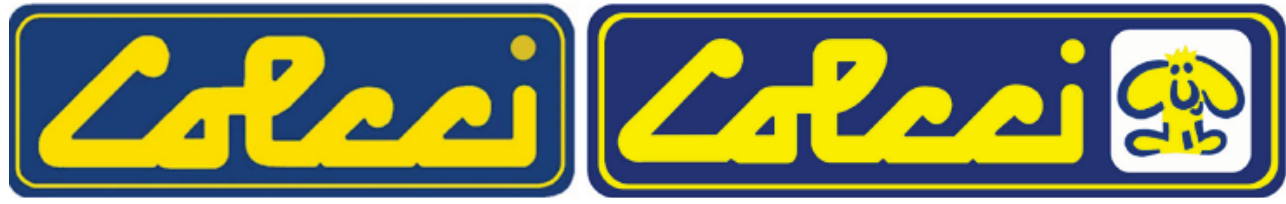

Figuras 2 e 3: Marca gráfica Colcci - Fonte: Melo Filho e Merlo ${ }^{16}$

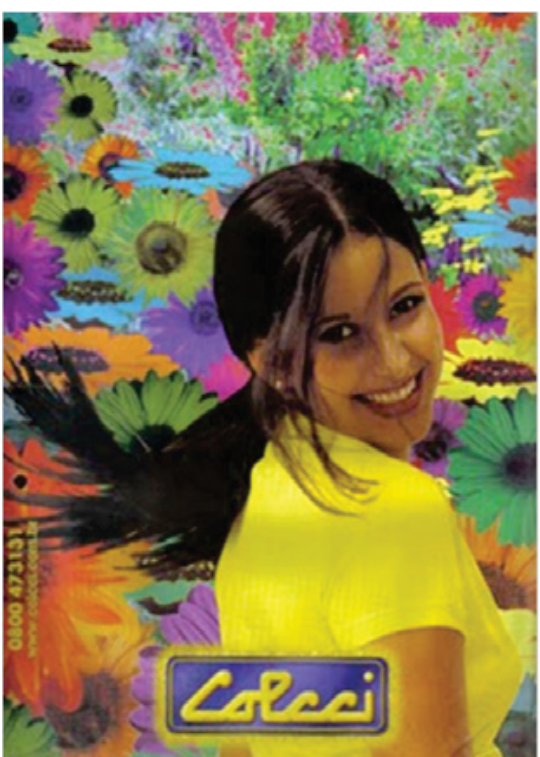

1996

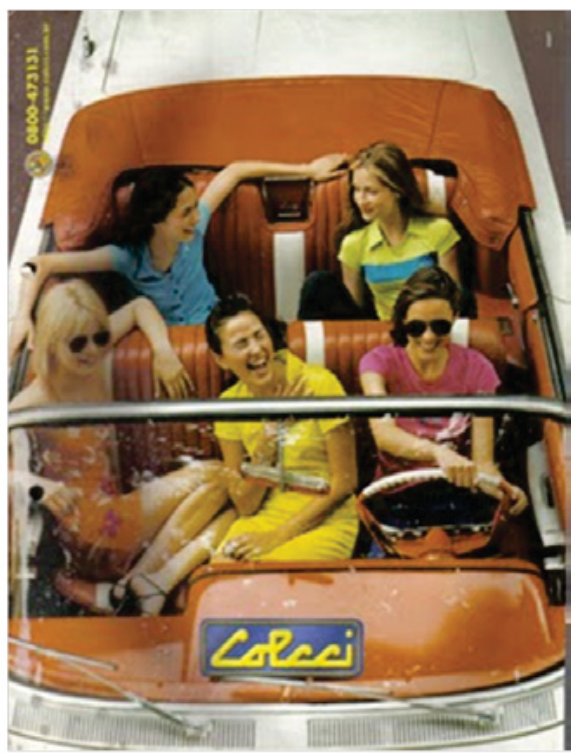

1997

Figuras 4 e 5: Campanhas Colcci 1996 e 1997.

Fonte: http://mundofififefe.blogspot.com

A marca gráfica com desenho associado ao público mais jovem e menos infantil foi apresentada em peças de propaganda, com imagens de jovens em momentos de descontração, alegria e energia (Fig. 4 e 5). 
Depois do ano de 1997, houve a evolução para outro posicionamento da marca, que foi apresentada como "marca de moda". Isso implicou no planejamento simbólico-mercadológico dos produtos e da marca, com vistas à atribuição de valor conceitual na comunicação e no posicionamento geral da marca no mercado. Os produtos da marca foram apresentados como sendo mais que vestuário, porque são produtos de moda. A faixa etária jovem que era atendida pela marca foi mais uma vez ampliada, ocupando a mente de jovens profissionais. O público foi delimitado por características "psicográficas", relacionadas ao gosto por arrojo, diferenciação e tendência de moda, além das qualidades funcionais e materiais.

Depois de passar por outras reformulações (Fig. 6 e 7), a marca gráfica assumiu sua configuração mais atual, indicando energia por meio de um grafismo de cor laranja e, ainda,expressando elegância e dinamismo no desenho das letras inclinadas do logotipo preto (Fig. 8). Entretanto, às vezes, a marca gráfica é representada apenas pelo logotipo, ainda, apresentando variações na cor das letras (Fig. 11).
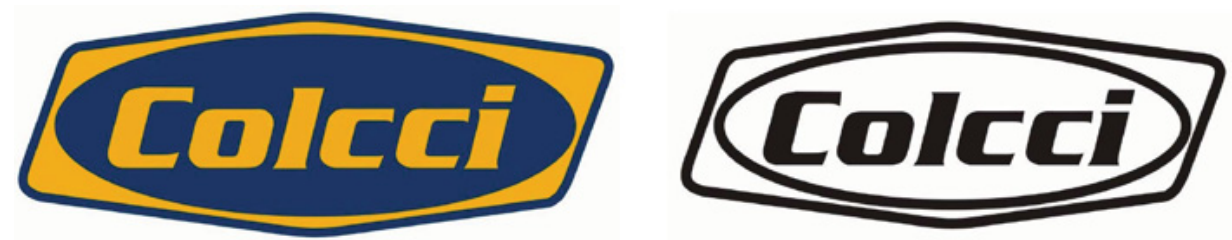

Figura 6 e 7: duas versões intermediárias da marca gráfica Colcci, com e sem cores. Fonte: Melo Filho e Merlo. ${ }^{17}$

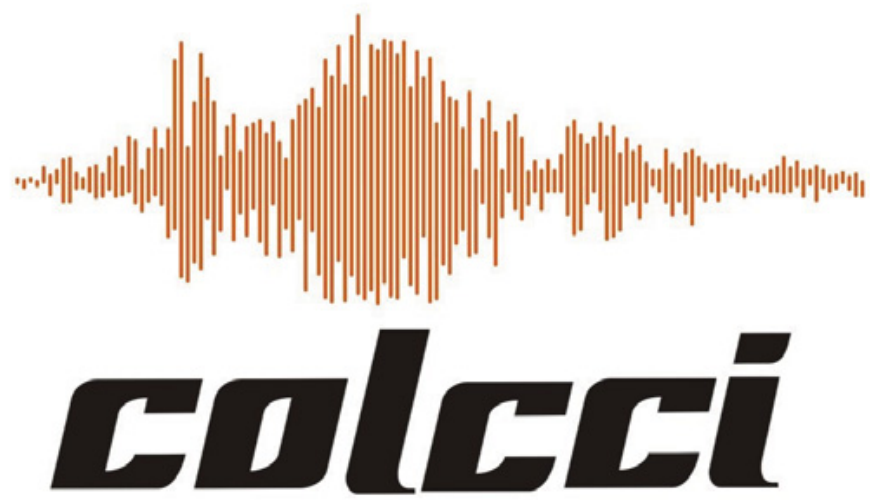

Figura 8: Marca gráfica Colcci, 1999/2000. Fonte: Melo Filho e Merlo. ${ }^{18}$ 
No ano 2000, o grupo empresarial Menegotti Industrial Ltda comprou a marca Colcci. Depois dessa primeira compra, houve uma série de outras aquisições, sendo que o grupo passou a se chamar AMC Têxtil Ltda. Em 2004, houve a compra da marca Sommer; em 2005 foi adquirida a marca Carmelitas e, em 2008, foram compradas as marcas Forum, Forum Tufi Duek, Tufi Duek e Triton. Além disso, houve a obtenção do licenciamento da marca Coca-Cola Clothing. Assim, a holding AMC Têxtil Ltda passou a representar o maior conglomerado de moda nacional. ${ }^{19}$

\section{A GESTÃO DA MARCA}

A empresa Colcci foi comprada ou incorporada ao grupo $A M C$ no momento em que seu conteúdo estilístico e sua marca já eram devidamente reconhecidos pelo público e pelo mercado como grife de moda. Isso assinalava que a gestão da marca no período anterior à incorporação havia sido bem sucedida.

Houve a necessidade de garantir as conquistas e, ainda, ampliar o sucesso da marca. Como um sinal de que isso foi devidamente considerado, até o ano de 2006, manteve-se a estilista-fundadora da empresa e sua equipe na condução do processo de desenvolvimento da marca Colcci. A imagem da marca é intimamente relacionada à identidade da empresa e, especialmente nas empresas de moda, a preservação da identidade e da cultura organizacional é necessária para garantir o 'DNA' da marca, cujo "caráter é definido por um conjunto de atributos bem próprios, que nenhuma outra empresa possui." 20

O momento da incorporação implica na entrada de um sócio majoritário ou controlador, indicando profundas mudanças e choques culturais. Todavia, é preciso considerar que não é interessante perder as características que tornaram a empresa e sua marca atraentes para o mercado incitando a incorporação. Assim, é necessário garantir a preservação dos aspectos interessantes e sua evolução no sentido de ampliar e explorar as potencialidades da empresa e da marca. Para tanto, mesmo que centralizada em uma equipe específica, a gestão da marca permeia toda a gestão organizacional, partindo do desenvolvimento de produtos e passando pelos processos internos e externos de comunicação e publicidade, que se estendem até as fases de comercialização e pós-venda.

No passado, há exemplos de marcas de moda que se estabeleceram sobre o carisma ou os dons de um estilista. Um exemplo clássico é a marca francesa Chanel, que foi construída sobre o mito de sua fundadora Coco Chanel (1883-1971). Atualmente, entretanto, a gestão da marca de moda prevê estratégias de sistematização objetiva da cultura, do conhecimento e da 
evolução da marca, destituindo-a da condição de propriedade intelectual de um estilista. Para Giusti ${ }^{21}$ a profissionalização da gestão da marca de moda, nas organizações atuais propicia a "rotinização do carisma". Assim, os dons característicos da marca, que determinam seu carisma, são tratados de maneira sistemática e objetiva, roteirizada e rotinizada, para não depender da intuição de um estilista genial.

Segundo Barcaro 22 "a imagem do estilista nos remete imediatamente ao conceito de criatividade, que é sem dúvida, o elemento mais importante e característico das empresas de moda". Apesar de que, tradicionalmente, os estilistas são legitimados pelas empresas de moda como principais responsáveis em compor a imagem da marca, esses não são os únicos, porque ao seu lado há outros que contribuem com a definição geral dos conceitos estilísticos e criativos. Entre esses, estão profissionais das áreas de Marketing e Design, entre outras. Há um conjunto de profissionais que representam o capital intelectual da empresa. ${ }^{23}$

A criatividade é necessária, mas não é suficiente na indústria da moda que também necessita de uma efetiva gestão da criatividade. Para Barcaro ${ }^{24}$ "sem a criatividade e conteúdos estilísticos originais a empresa de moda não existe, também é verdade que sem uma boa gestão e uma rigorosa administração a empresa de moda não resiste".

Antes de ser reconhecido pelo público consumidor, o estilo da marca deve fazer parte do conhecimento organizacional para, como foi dito anteriormente, ser expresso em todas as etapas, desde a criação e produção até a comercialização e o pós-venda. A identidade corporativa é composta por valores e atitudes coletivos, os quais determinam a sinergia do processo, como resultado de uma integração bem sedimentada (Fig. 9). Isso é expresso nas atitudes da empresa e propõe os fundamentos éticos e estéticos da marca, compondo a "gestalt" da marca. ${ }^{25}$

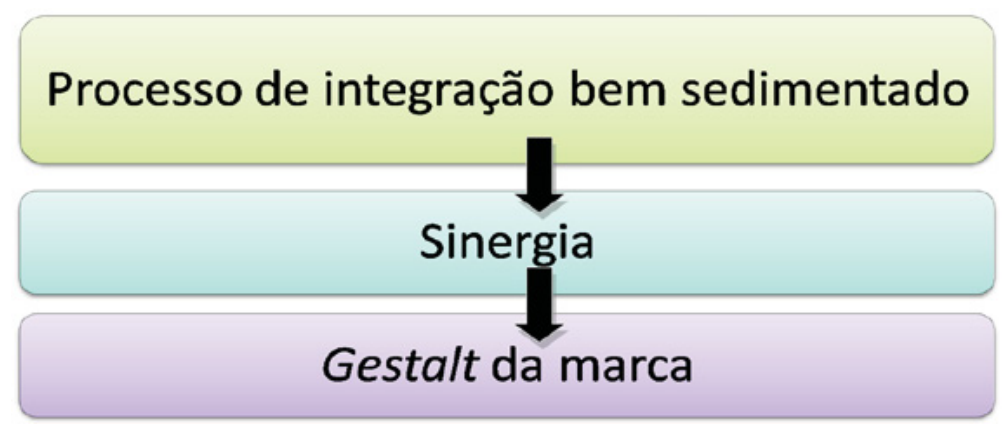

Figura 9: Etapas de composição da Gestalt da marca. Fonte: adaptação criada pelos autores, 2011 
O conhecimento empresarial, bem trabalhado e gerido, pode ser expresso por meio da comunicação integrada da marca, que é direcionada ao público interno e ao público externo. Essa comunicação se estabelece por diversos meios, a começar por expressões e atitudes pessoais que são refletidas nos procedimentos, nos processos e nos produtos. Para Sampaio ${ }^{26}$, a marca é uma "experiência total", como o conceito de "gestalt", oriundo da escola alemã de psicologia: "A marca é compreendida pela sua gestalt. E a gestalt é formada de pequenas parcelas que o consumidor só entende como parte de um sistema, nunca como um fato isolado". Isso envolve a comunicação de sensações e sentimentos, conscientes e inconscientes, que em parte estabelecem ideias ou atributos conceituais para a marca. $\mathrm{O}$ conhecimento da marca como experiência permite o fortalecimento dos seus valores, minimizando o risco de confundir-se sua identidade com outras marcas.

O conhecimento de cada empresa ou marca específica é ainda mais necessário no contexto de uma holding, devido a proximidade entre as empresas de um mesmo grupo. Mas, além disso, as empresas específicas também devem acompanhar os objetivos organizacionais da holding. Um exemplo de sucesso na categoria luxury fashion industry (indústria da moda de luxo) é Moët Hennessy Louis Vuitton (LVMH), como a maior holding internacional de moda, controlando dezenas de marcas em setores que vão do vestuário, passando por acessórios de moda e até perfumes e vinhos. No caso, o atributo luxo é o conceito integrador de todas as suas marcas.

A holding AMC Têxtil, proprietária da marca Colcci, sistematiza a entrada de insumos para todo o grupo, controlando de modo geral o processo produtivo, até a etapa de comercialização. Isso aumenta seu poder junto aos fornecedores e permite o controle da produtividade de todas as empresas. Todavia, as especificidades de cada uma das marcas requerem estratégias específicas de comunicação, a começar pela integração e sinergia do público interno até as ações e aparições públicas das empresas que caracterizam o campo de composição da imagem da marca nas mentes do público consumidor e na cultura de mercado.

\section{O DISCURSO DA MARCA COLCCI}

Em 2007, o grupo AMC Têxtil contratou a estilista Jessica Lengyel para exercer a direção criativa da marca Colcci. Isso foi possível porque o conteúdo estilístico da marca havia sido incorporado à organização, deixando de ser propriedade da estilista fundadora. Além disso, houve um alto investimento, por parte do grupo incorporador, em campanhas publicitárias para divulgar 
e consolidar ainda mais a marca, permitindo que outros profissionais participassem de sua expressão cultural e, também, explicitando a imagem da marca projetada pela holding.

Outros símbolos poderosos foram associados à marca Colcci, o maior desses foi resultado da contratação e associação da marca com a imagem da übermode ${ }^{27}$ Gisele Bündchen. Pois, aos olhos do público consumidor e do mercado, isso determinou definitivamente a marca Colcci como uma marca de moda, evidenciando o direcionamento do foco da marca para o mercado de moda.

O apelo proposto envolveu o público jovem e sensível aos apelos glamourosos do mundo fashion. Assim, a imagem de uma marca de moda jovem com conteúdo divertido e irreverente, como as nas campanhas de 1996 e 1997 (Fig. 4 e 5), foi substituída por expressões de 'glamour', 'poder' e 'sedução', como na campanha de 2005 (Fig. 10).

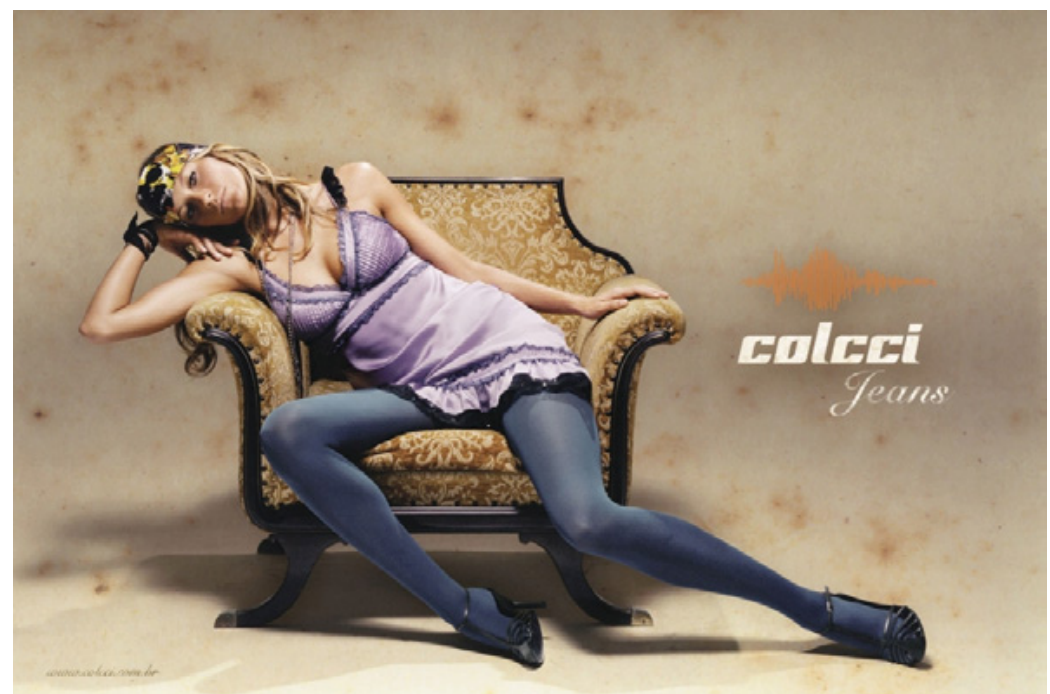

Figura 10: Gisele Bündchen - Campanha Colcci - 2005. Fonte: http://www.garcaonline.com.br/?gonline $=$ vitrine\&eloja $=y \&$ site $=Y$ \&codlojacanal

Como personagem pública, a imagem de Gisele Bündchen não era de uma menina moça, mas de uma mulher jovem, combinando com o perfil psicográfico do novo posicionamento da marca. Porém, nas primeiras campanhas publicitárias a modelo da marca apareceu vestida como uma jovem de 18 anos, estabelecendo ainda alguma relação com a imagem tradicional da marca Colcci. Posteriormente, houve a gradativa transformação da figura da modelo, apresentando-a como adulta e demarcando a já citada expansão da marca para outros setores da moda jovem. 
Baudrillard ${ }^{28}$ assinala a "economia política do signo", indicando o valor de signo ou o valor simbólico dos produtos tangíveis ou intangíveis, como aspecto mais característico e mais valorizado do consumo contemporâneo. A visão proposta é uma crítica à sociedade de consumo que, depois de ceder ao feitiço da mercadoria, como foi assinalado por Karl Marx (1818-1883), agora mitifica e cultua os produtos por seu valor simbólico.

A despeito da crítica, a atribuição de valor simbólico aos produtos influencia diretamente nas vendas e nos lucros decorrentes do comércio de produtos, sendo que a marca é o sistema simbólico por excelência. Na moda, o endosso da marca na identificação glamourosa dos produtos, cercando-os com os requintes e a espetacularização do discurso publicitário, propõe a mitificação e o culto aos lançamentos de cada estação.

Na coleção outono/inverno-2011, a marca Colcci apresenta a produção de novos estilistas, Adriana Zucco e Gisele Moraes, seguindo a tendência da moda em geral e substituindo os desfiles conceituais por outros que apresentam peças comerciais. Outro recurso que complementa essa tendência mais comercial é a aparição de celebridades, atuando como modelos na passarela. Assim, a marca Colcci apresenta uma coleção coerente e concisa, trazendo uma narrativa de encantamento e a presença de celebridades internacionais, além de modelos profissionais. A passarela da marca, durante o evento São Paulo Fashion Week (SPFW - 2011), apresentou o ator americano Ashton Kutcher e as modelos brasileiras Gisele Bündchen e Alessandra Ambrósio (Fig. 11).

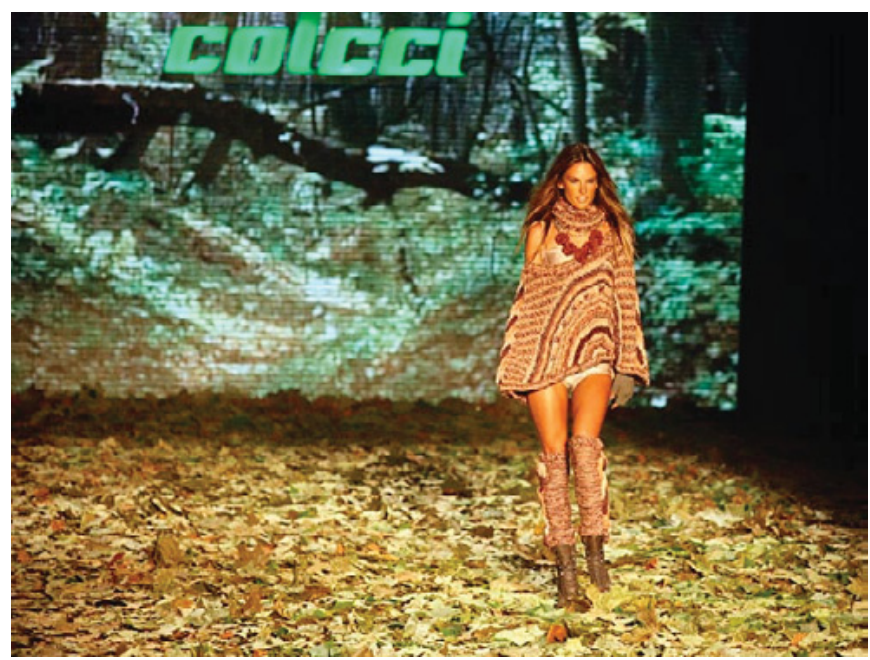

Figura 11: Alessandra Ambrósio - desfile SPFW Colcci Inverno 2011. Fonte: http://www.aoladodamoda. com/2010/12/line-up-sao-paulo-fashion-week.html 
O processo de "crescimento" da marca Colcci é representado nas suas cinco linhas de segmentação do mercado: (1) há a linha Fun, que se destina ao público infantil; (2) a linha $T$ é voltada aos pré-adolescentes, entre 12 e 14 anos; (3) a linha Jeanswear, que é carro-chefe da marca, também incorporou a produção de malhas; (4) a linha Silverlab, que é a linha feminina Premium, e (5) a linha PM, que produz roupas de festa e alfaiataria para homens e mulheres.

Apesar de haver essas subdivisões da marca, todas as linhas são identificadas e endossadas pelo nome Colcci, sendo que somente a linha infantil não é apresentada em desfile nas passarelas do evento brasileiro que, no início de cada temporada divulga as marcas de moda, São Paulo Fashion Week (SPFW).

O discurso visual da marca Colcci começou a ser constituído, dirigindose ao público infanto-juvenil, sendo demarcado pela imagem da mascote Digby (Fig. 1). Em seguida, o discurso foi ampliado aos jovens, ainda em brincadeiras adolescentes, com uma abordagem externa e objetiva, apresentando um logotipo funcional, imagens diurnas, cores de matéria plástica, compondo temáticas de primavera e de parques de diversões, conforme foi visualmente registrado nas campanhas publicitárias da marca Colcci dos anos 1996/1997 (Fig. 4 e 5). A consolidação como marca de moda substituiu a imagem da mascote da marca pela famosa manequim gaúcha, associando a marca à imagem de Gisele Bündchen. Assim, contradizendo a anterior, a abordagem passou a ser interna, introspectiva e subjetiva, com redução em variedade e vivacidade das cores, dramatização da pose e mitificação do ambiente, como um mundo fora do tempo atual (Fig. 10).

A marca gráfica (Fig. 8) agora aparece como 'coisa de gente grande', o grafismo laranja expressa energia, assim como o registro de sismógrafos ou outros aparelhos e, como uma distante referência ao estilo gótico, as letras propõem elegância geométrica com formas angulosas, mesclando solidez com a dinamicidade que é sugerida em sua leve inclinação.

Houve reincidências na associação da marca com celebridades e modelos famosas, como Alessandra Ambrósio, também, há sugestões de que o logotipo da marca tende a ser apresentado sozinho e em cores variadas (Fig. 11).

As imagens apresentadas são sintomáticas com relação às mudanças de posicionamento da marca, considerando-se que, inicialmente, o foco foi qualidade de produto. Mas, posteriormente, depois de alcançar o reconhecimento da qualidade, a gestão da marca direcionou seus esforços com foco no mercado, visando posicionar simbolicamente o nome Colcci como marca de moda. A associação entre a marca e a modelo Gisele Bündchen também foi sintomática. Porém, juntamente com essa associação foi promovida 
uma evidente transformação no ambiente visual da comunicação da marca, substituindo-se a abordagem externa e objetiva pela abordagem interna e subjetiva, que propiciou a mitificação da marca (Fig. 10).

O percurso discursivo da marca Colcci é, ainda, um exemplo de transição no contexto da indústria têxtil e de vestuário do estado de Santa Catarina. Pois, a despeito da tradição artesanal e familiar da indústria estadual de produtos têxteis e de vestuário, sendo originalmente focada na qualidade do produto, seu foco e sua atuação também estão sendo direcionados ao mercado de moda. A ampliação focal depende da revisão estilística da produção que é determinada pelo conceito de moda representado a exemplo da roupa, com suas formas, cores, volumes e caimento e modelagens. Todavia, além das mudanças e ampliações nas linhas de produtos, é necessário que a comunicação da marca seja condizente com suas aspirações. Assim, as parcerias, as atitudes, os símbolos e toda a publicidade, considerando-se principalmente a propaganda, devem expressar a evolução do posicionamento da marca diante do mercado e especialmente nas mentes do público consumidor.

O percurso visual da marca, que foi aqui sintetizado em dez figuras, indica expressões das alterações de posicionamento, seja diretamente no desenho da marca gráfica ou na visualidade da publicidade e dos desfiles. Há diversas outras imagens participantes do percurso/discurso visual da marca Colcci. Pois, diversas vezes, houve o aprimoramento do desenho de sua marca gráfica, com diferentes combinações dos elementos existentes ou com a substituição de parte desses elementos. As imagens da publicidade também foram muito diversas. Porém, as figuras aqui apresentadas ilustram momentos cruciais na comunicação, como sinais ou sintomas da gestão da marca em estudo.

A marca Colcci infanto-juvenil representada pela mascote Digby (Fig. 1) poderia, por exemplo, ter evoluído como marca de moda na vertente Surfwear, com vestuário e acessórios para surfistas e moda praia. Assim, seria estabelecida uma linha de moda em que a mascote continuaria fazendo sentido como símbolo da marca. Todavia, o que as figuras indicam é que foi seguido outro caminho, no qual a linha Jeanswear foi desenvolvida como carro-chefe da marca, apontando ainda para o requinte de outras linhas mais sofisticadas. Esse percurso exigiu mudanças e variações que impediram o sentido de continuidade no discurso visual da marca, evidenciando os saltos e as mudanças de direção que ocorreram durante o percurso. ${ }^{29}$ 
O discurso da marca Colcci: um recorte visual sobre o processo de transição da

indústria de moda catarinense

\section{NOTAS}

l GIUSTI, N. A indústria da moda nos estudos organizacionais: mitos, equívocos, e perspectivas de pesquisa. In: SORCINELLI, P. (Org.). Estudar a moda: Corpos, vestuários, estratégias. São Paulo: Ed. Senac, 2008. p. 122.

2 GASTINEAU, Gary L.; KRITZMAN, Mark P. Dicionário de administração de risco financeiro. São Paulo: Bolsa de Mercadorias \& Futuros, 1999.

3 PERASSI, Richard L. S. A visualidade das marcas institucionais e comerciais como campo de significação. 200 I. Tese, PUC/SP, São Paulo, 2001.

4 MANARESI, A. Orientação para o mercado nas empresas de moda. In: SORCINELLI, P. (Org.). Estudar a Moda: Corpos, vestuários, estratégias. São Paulo: Ed. Senac, 2008. p. 134.

5 ABIT - Associação Brasileira da Indústria Têxtil e de Confecção. Relatório Setorial da Indústria Têxtil Brasileira 2010. São Paulo, 27 Mar. 20II. Disponível em: < http:// www.abit.org.br/site/noticia_detalhe.asp?controle =2\&id_menu=20\&idioma $=$ PT\&id noticia $=2704 \&>$. Acesso em: abr. 201 I.

6 As importações brasileiras de vestuário, no primeiro bimestre de 201 I, registraram alta de $70,5 \%$ em relação ao mesmo período do ano passado e chegaram a US $\$ 268,3$ milhões. Vale à pena ressaltar, que deste montante, US\$175, I milhões são de produtos chineses. No primeiro bimestre de 2010 , as importações de vestuário da China ficaram em US \$95,3 milhões. In: Déficit comercial do setor têxtil e de Confecção. ABIT - Associação Brasileira da Indústria Têxtil e de Confecção, São Paulo, 27 Mar. 20 I I. Disponível em: < http:// www.abit.org.br/site/noticia_detalhe.asp?controle=2\&id_menu=20\&idioma=PT\&id noticia $=3137 \& \#$ ancora $>$. Acesso em: abr. 201 l.

7 AAKER, David A. Marcas, Brand Equity: Gerenciando o Valor da Marca. São Paulo: Negócio, 1998. AAKER, David A; JOACHIMSTHALER, Erich. Como construir marcas líderes. Porto Alegre: Bookman, 2007.

8 MARTINS, José Roberto. Branding: um manual para você criar e gerenciar marcas. São Paulo: Negócio, 2000/2006.

9 MATTOS, A. Marcas mais valiosas retomam nível pré-crise, aponta Interbrand. Revista Valor On-line. Disponível em: <http://www.valoronline.com.br/online/ interbrands/45368/309408/>. Acesso em: abr. 20II.

10 ÉPOCA NEGÓCIOS. Google é a marca mais valiosa do mundo, segundo pesquisa. Disponível em: <http://epocanegocios.globo.com/Revista/Common/>. Acesso em: abr. 2011 .

"' GLOBAL BRANDS. Arno: avaliação da marca e branding. Disponível em: < http://www. globalbrands.com.br/arno-avaliacao-da-marca-e-branding/ > . Acesso em: abr. 20 I I.

${ }^{12}$ COSTA, Joan. A imagem da marca: Um fenômeno social. São Paulo: Rosari, 2008. 
${ }^{13}$ Idem, Ibidem.

${ }^{14}$ DE MASI, D. (Coord.). O futuro da moda de Santa Catarina: previsões para o período 2008-20 I2. Tubarão: Unisul, 2008. p. 25.

15 MELO FILHO, A.; MERLO, M. O design da marca Colcci: história e construção. In: Gisela Belluzzo; Jofre Silva (Org.). DAMT: Design, arte, moda e tecnologia. Bauru, SP: Rosari, 2010. p. 422.

${ }^{16}$ Idem, Ibidem, p. 422-3.

17 Idem, Ibidem, p. 430-I.

${ }^{18}$ Idem, Ibidem, p. 43I.

19 SCHLICKMANN, Larissa Volpato. Holding de moda. 2009. 55 f. TCC (Bacharelado em Moda) - Universidade do Estado de Santa Catarina, Florianópolis, 2009. Disponível em: < http://www.pergamumweb.udesc.br/biblioteca/index.php?resolution2=1024_| > Acesso em: 09 mar. 2011.

${ }^{20}$ FASCIONI, Lígia. DNA Empresarial: identidade corporativa como referência estratégica. São Paulo: Integrare, 2010 . p. 22.

${ }^{21}$ GIUSTI, op. cit. p. 122.

22 BARCARO, A. Os processos de uma empresa de moda. In: SORCINELLI, P. (Org.). Estudar a Moda: Corpos, vestuários, estratégias. São Paulo: Ed. Senac, 2008. p. I 44.

${ }^{23}$ MACEDO, M. et al. Gestão do conhecimento organizacional. Florianópolis: UFSC, 20 I 0.

${ }^{24}$ BARCARO, op. cit. p. 145.

${ }^{25}$ SAMPAIO, Rafael. Propaganda de A a Z: como usar a propaganda para criar marcas e empresas de sucesso. Rio de Janeiro: Campus, 1997.

${ }^{26}$ Idem, Ibidem, p. $164-5$.

27 Übermodel (termo em alemão para super modelo) seria a mais alta categoria em legitimidade e reconhecimento entre as modelos e manequins; estando, assim, localizado hierarquicamente acima do termo topmodels, que se refere a modelos que tem sucesso reconhecido.

${ }^{28}$ BAUDRILLARD, J. Para uma Crítica da Economia Política do Signo. Rio de Janeiro: Elfos, 1995. 